\title{
Kesalahan siswa dalam menyelesaikan soal Olimpiade SMP konten aljabar
}

\author{
Yoga Baskara Setiawan *, Hapizah Hapizah, Cecil Hiltrimartin \\ Pendidikan Matematika, Universitas Sriwijaya. \\ Jalan Raya Palembang-Prabumulih Indralaya Ogan Ilir 30662, Indonesia \\ * Corresponding Author. E-mail: yogabaskarasetiawan@gmail.com \\ Received: 26 January 2018; Revised: 26 February 2018; Accepted: 31 December 2018
}

\begin{abstract}
Abstrak
Penelitian ini merupakan penelitian deskriptif kualitatif yang bertujuan untuk mengetahui dan mendeskripsikan kesalahan siswa dalam menyelesaikan soal olimpiade SMP konten aljabar. Jenis penelitian yang digunakan adalah studi kasus. Subjek penelitian adalah perwakilan siswa kelas IX SMP Negeri 1 Palembang dengan jumlah siswa 22 orang. Teknik pengumpulan data pada penelitian adalah tes tertulis dan wawancara. Analisis data tes dan wawancara mengikuti prosedur Newman Error Analysis. Hasil penelitian menunjukkan bahwa kesalahan-kesalahan yang dilakukan siswa dalam menyelesaikan soal olimpiade SMP konten aljabar terdiri dari kesalahan dalam memahami soal, kesalahan dalam transformasi meliputi penggunaan rumus atau prosedur tidak relevan dan tidak mengetahui prosedur yang digunakan, dan kesalahan dalam proses perhitungan meliputi kesalahan menggeneralisasi pola ke bentuk umum dan tidak menyelesaikan prosedur penyelesaian.
\end{abstract}

Kata kunci: Newman error analysis, Olimpiade, aljabar

\section{Students' error in solving junior high school Olympiad problem on algebra content}

\begin{abstract}
This research is a qualitative descriptive research that aims to find out and to describe the students' error in solving junior high school Olympiad on algebra content. Type of this research is case study. The subjects of the study were the students of class IX SMP Negeri 1 Palembang with 22 students. Data collection techniques in this research are written tests and interviews. Analysis of test and interview data follows Newman Error Analysis procedure. The results of the research show that the students' error in solving junior high school problem on algebra content consist of errors in understanding the problem, error in transformation error includes the use of irrelevant formulas or procedures and do not know the procedures used, and errors in the calculation process include errors generalize patterns to the general form and did not complete the settlement procedure.
\end{abstract}

Keywords: Newman error analysis, Olympic, algebra

How to Cite: Setiawan, Y., Hapizah, H., \& Hiltrimartin, C. (2018). Kesalahan siswa dalam menyelesaikan soal olimpiade SMP konten aljabar. Jurnal Riset Pendidikan Matematika, 5(2), 233-243. doi:https://doi.org/10.21831/jrpm.v5i2.18191

Permalink/DOI: https://doi.org/10.21831/jrpm.v5i2.18191

\section{PENDAHULUAN}

Olimpiade Sains Nasional (OSN) merupakan kegiatan lomba bidang Matematika, IPA, IPS yang diselenggarakan oleh Direktorat Jenderal Pendidikan Dasar dan Menengah dalam rangka peningkatan mutu pendidikan dan dalam rangka penuntasan wajib belajar yang bermutu (Direktorak Dikdasmen Kemendikbud RI, 2017). Kegiataan OSN SMP dilaksanakan sejak tahun 2003. Pada periode 2003 sampai dengan 2009 bidang yang dilombakan terdiri dari Matematika, Biologi, dan Fisika. Pada tahun 2010, IPS dimasukkan ke dalam bidang yang dilombakan, sehingga sejak tahun itu bidang lomba menjadi 4 bidang. Kemudian pada tahun 2015 bidang Biologi dan Fisika digabung menjadi satu bidang yaitu bidang IPA (Direktorat Dikdasmen Kemendikbud RI, 2017). Tujuan umum OSN SMP dalam Panduan OSN SMP 2017 adalah untuk meningkatkan mutu pendidikan khususnya 
bidang Matematika, IPA dan IPS yang berasaskan pendidikan karakter. Selain itu, penyelenggaraan OSN SMP bertujuan untuk memotivasi dan menumbuhkembangkan atmosfir kompetisi yang sehat serta mendorong sekolah berperan memfasilitasi siswa untuk meningkatkan kemampuan akademis dalam bidang Matematika, IPA dan IPS (Direktorat Dikdasmen Kemendikbud RI, 2017).

Dalam penyelenggaraan OSN SMP khususnya dalam mata pelajaran matematika, masih banyak siswa-siswi khususnya yang berasal dari Sumatera Selatan masih kesulitan dalam mengerjakan soal-soal olimpiade. Kesulitan yang dialami siswa tersebut mengakibatkan terjadinya kesalahan dalam menyelesaikan soal-soal olimpiade. Hal ini didukung oleh hasil OSN Matematika SMP 2016 di Kota Palembang dimana tidak ada satupun siswa yang berasal dari Sumatera Selatan yang mendapatkan medali baik medali emas, medali perak, maupun medali perunggu (Direktorat PSMP Kemendikbud RI, 2016). Sedangkan pada OSN Matematika SMP tahun 2017, siswa-siswi dari Sumatera Selatan hanya memperoleh 1 perak dan 1 perunggu (Direktorat PSMP Kemendikbud RI, 2017).

Salah satu materi yang sering diujikan dalam olimpiade mata pelajaran matematika adalah aljabar. Aljabar merupakan cabang matematika yang menggunakan pernyataanpernyataan matematis untuk menggambarkan hubungan antara berbagai hal (Sukmawati, 2015). Aljabar adalah salah satu materi yang diujikan dalam Olimpiade Siswa Nasional (OSN) Matematika SMP selain bilangan, geometri, serta statistika dan peluang. Dalam pedoman OSN Matematika SMP 2017, materi-materi aljabar yang diujikan terdiri dari pengertian himpunan, notasi himpunan, operasi himpunan, pengertian dan grafik relasi dan fungsi, operasi fungsi linear dan kuadrat beserta sifat-sifatnya, perbandingan senilai dan berbalik nilai, operasi aljabar melibatkan bilangan rasional, operasi aljabar melibatkan bilangan berpangkat, operasi aljabar melibatkan bilangan berbentuk akar, persamaan linear satu dan dua peubah, pertidaksamaan linear satu peubah, persamaan kuadrat satu peubah, pertidaksamaan linear dan kuadrat dua peubah, sistem persamaan linear dua peubah, pola barisan, barisan dan deret aritmatika, barisan dan deret geometri.

Dalam konteks pembelajaran matematika, aljabar sangat bermanfaat dalam menggeneralisasi dan menyelesaikan bermacam- macam permasalahan (NCTM, 2008). Selain itu, Suhaedi (2013) mengungkapkan bahwa aljabar merupakan materi yang sangat penting bagi siswa untuk dipahami, karena materi tersebut adalah salah satu yang banyak digunakan dalam aktivitas sehari-hari. Dalam Kurikulum 2013, menguasai materi aljabar merupakan suatu hal yang wajib bagi siswa khususnya siswa SMP. Hal ini dapat dilihat dari materi aljabar dipelajari siswa SMP dari kelas VII hingga kelas IX dan banyaknya materi yang memerlukan konsep aljabar seperti geometri, stastistika, dan peluang.

Fakta di lapangan menunjukkan bahwa tingkat penguasaan materi aljabar siswa masih rendah. Hal ini dapat dilihat dari kesulitan siswa dalam mengerjakan soal-soal aljabar. Hal tersebut sesuai dengan pendapat Tadda (2016) yang mengatakan bahwa masih banyak siswa yang mengalami kesulitan pada materi aljabar. Hal ini juga didukung oleh pendapat Ukhti (2013) yang menyatakan bahwa aljabar menjadi materi dalam olimpiade dengan tingkat penguasaan yang paling rendah selain geometri. Kesulitan ini disebabkan oleh minat siswa dalam mempelajari aljabar yang rendah (Ukhti, 2013). Kesulitan tersebut dapat mengakibatkan terjadinya kesalahan saat menyelesaikan soal aljabar (Tadda, 2016).

Salah satu SMP Unggulan di Kota Palembang yaitu SMP Negeri 1 Palembang. Berdasarkan hasil wawancara dengan guru pembimbing olimpiade matematika SMP Negeri 1 Palembang, diketahui bahwa setiap tahun mereka selalu mengikutsertakan siswa mereka dalam ajang OSN Matematika Se-SMP kota Palembang dan dalam tiga tahun terakhir paling tinggi hanya mencapai tingkat provinsi, hal ini disinyalir disebabkan karena pemahaman konsep matematika siswa yang kurang, kesalahan siswa dalam mengerjakan soal, dan pembinaan oleh guru yang belum maksimal. Oleh karena itu, penting untuk menganalisis kesalahan siswa, sebab analisis kesalahan sangat berguna untuk mengetahui kesalahan-kesalahan siswa tersebut supaya nantinya dapat memberikan bantuan kepada guru yang bersangkutan agar memilih metode pembinaan yang lebih tepat dari metode sebelumnya, sehingga kesalahan-kesalahan yang dibuat siswa tersebut tidak terjadi kembali (Trapsilo, 2016).

Menurut Trapsilo (2016) kesalahan merupakan penyimpangan terhadap hal yang benar yang sifatnya sistematis, konsisten, maupun insidental pada daerah tertentu. Selain itu, menurut Lipianto dan Budiarto (2013), 
kesalahan merupakan kekeliruan atau penyimpangan terhadap sesuatu yang benar, prosedur yang sudah ditetapkan sebelumnya atau penyimpangan dari sesuatu yang diharapkan. Jadi, dapat disimpulkan analisis kesalahan adalah suatu penyelidikan terhadap kekeliruan atau penyimpangan terhadap sesuatu hal yang benar atau prosedur yang telah ditetapkan sebelumnya yang bersifat sistematis, konsisten, maupun insidental untuk mengetahui kekeliruan atau kesalahannya.

Kesalahan siswa dapat diidentifikasi dengan suatu pedoman, salah satunya yaitu melalui Newman Error Analysis (NEA). Abdullah, Abidin, dan Ali (2015) menyatakan tahapan atau prosedur Newman Error Analysis yaitu, reading error (kesalahan membaca), comprehension error (kesalahan pemahaman), transformation error (kesalahan mentransformasikan), process skill error (kesalahan keterampilan proses), dan encoding error (kesalahan menyimpulkan). Lebih lanjut, Singh, Rahman, dan Hoon (2010) menjelaskan tahapan atau prosedur Newman error meliputi kesalahan membaca (reading error) yaitu suatu kesalahan dalam: (a) mengenal atau membaca simbol-simbol pada soal; (b) mengerti makna simbol pada soal; dan (c) mengerti makna kata pada soal. Kesalahan pemahaman (comprehension error) adalah kesalahan dalam: (a) memahami arti keseluruhan dari soal; dan (b) menuliskan dan menjelaskan apa yang diketahui dan ditanyakan pada soal. Kesalahan transformasi (transformation error) yaitu kesalahan siswa dalam: (a) menerjemahkan masalah ke dalam model matematika; (b) menentukan rumus yang akan digunakan; (c) menentukan operasi matematika atau rangkaian operasi untuk penyelesaian soal tersebut dengan benar. Kesalahan keterampilan proses (process skill error) yaitu kesalahan dalam: (a) proses atau algoritma untuk menyelesaikan soal meskipun telah menentukan rumus yang tepat; dan (b) menjalankan prosedur secara benar meskipun telah mampu menentukan operasi matematika yang akan digunakan. Kesalahan menyimpulkan (encoding error) adalah kesalahan siswa dalam: (a) menuliskan jawaban akhir; dan (b) tidak menuliskan jawaban akhir.

Terkait dengan kemampuan siswa dalam menyelesaikan soal-soal aljabar, beberapa peneliti telah melakukan penelitian yang menyelidiki jenis-jenis kesalahan siswa dalam menyelesaikan soal-soal aljabar. Kesalalahan siswa dalam menyelesaikan soal aljabar menurut Ridwan (2016) adalah kesalahan menentukan rumus atau prosedur, tidak melanjutkan prosedur penyelesaian, kesalahan dalam operasi aljabar, dan kesalahan dalam menggunakan prosedur penyelesaian. Sedangkan kesalahan siswa dalam menyelesaikan soal aljabar menurut Herutomo dan Saputro (2014) adalah kesalahan siswa dalam mengerjakan soal aljabar adalah kesalahan memahami huruf sebagai label, kurang memahami variabel sebagai sesuatu yang belum diketahui nilainya, kesalahan memahami variabel sebagai generalisasi bilangan, kesalahan dalam membentuk persamaan, kurang memahami sifat distributif, kesalahan representasi, dan kesalahan dalam operasi hitung aljabar.

Berdasarkan latar belakang dan kajian literatur yang telah dikemukakan sebelumnya, maka analisis kesalahan siswa dalam menyelesaikan soal-soal olimpiade pada materi aljabar. Dengan demikian, penelitian ini bertujuan untuk mengetahui dan menyelidiki kesalahan-kesalahan siswa dalam menyelesaikan soal-soal olimpiade pada materi aljabar.

\section{METODE}

Penelitian ini merupakan penelitian deskriptif kualitatif jenis studi kasus yang bertujan untuk mengetahui kesalahan siswa kelas IX SMP Negeri 1 Palembang, Sumatera Selatan, Indonesia dalam menyelesaikan soal olimpiade SMP konten aljabar. Subjek penelitian ini adalah 22 siswa kelas IX SMP Negeri 1 Palembang yang pernah mengikuti olimpiade matematika. Penelitian ini dilaksanakan pada tanggal 10 Oktober 2017 sampai dengan 21 November 2017 di SMP Negeri 1 Palembang.

Prosedur penelitian terdiri dari tahap persiapan, tahap pengumpulan data, dan tahap analisis data. Pada tahap persiapan, peneliti menyiapkan instrumen tes yang terdiri dari lima soal dan pedoman wawancara yang dibuat berdasarkan tahapan Newman error. Kemudian, peneliti menentukan 22 subjek penelitian dengan syarat pernah mengikuti olimpiade atau yang berkemampuan tinggi. Kemudian, peneliti melakukan pengumpulan data dengan memberikan soal tes kepada subjek penelitian dan wawancara setelah data hasil tes dianalisis. Selanjutnya, data yang diperoleh dianalisis yang didasarkan pada tahapan Newman error.

Pengumpulan data dilakukan melalui tes dan wawancara. Instrumen yang digunakan antara lain soal tes OSN SMP dan panduan wawancara. Soal tes digunakan untuk memperoleh data terkait cara siswa menjawab soal-soal olimpiade. Soal tes terdiri dari 5 soal uraian yang telah divalidasi. Wawancara digunakan untuk memperoleh data pendukung terkait dengan 
kesalahan-kesalahan yang dilakukan siswa dalam menjawab soal-soal olipiade. Wawancara dalam penelitian ini bersifat tak terstruktur.

Data dianalisis mengikuti prosedur Newman Error Analysis. Hasil jawaban siswa yang didapat dari tes dianalisis guna menentukan jenis kesalahan yang dilakukan siswa berdasarkan prosedur atau tahapan Newman error. Dari hasil analisis jawaban siswa, ditentukan subjek yang akan diwawancara yang dapat mewakili semua jenis kesalahan yang terjadi. Pada wawancara, subjek diwawancarai sesuai kesalahan yang dilakukannya.

\section{HASIL DAN PEMBAHASAN}

Penelitian ini terdiri dari tiga tahapan, yaitu tahap persiapan, tahap pelaksanaan, dan tahap analisis data. Pada tahap persiapan, peneliti melakukan studi ke SMP Negeri 1 Palembang yang bertujuan untuk mendapatkan beberapa informasi untuk penunjang penelitian, membuat dan menyusun instrumen penelitian, dan menentukan subyek penelitian yang akan dipilih.

Pada tahap pelaksanaan, peneliti melakukan pengambilan data dengan tes tertulis dan wawancara. Tes tertulis dilaksanakan pada tanggal 10 Oktober 2017, dengan memberikan 5 soal kepada 22 siswa yang menjadi subjek penelitian, sedangkan wawancara dilaksanakan pada tanggal 21 November 2017, dengan mewawancarai 5 siswa yang terpilih berdasarkan analisis data tes. Pada tahap pelaksanaan ini didapat data berupa jawaban siswa dan rekaman wawancara.

Pada tahapan analisis data, peneliti menganalisis kesalahan yang dilakukan subjek penelitian melalui hasil jawaban tes siswa. Selain itu, peneliti juga menganalisis kesalahan dari hasil wawancara. Pada tahapan analisis data ini, peneliti menganalisis kesalahan siswa berdasarkan prosedur Newman error yang terdiri dari reading error, comprehension error, transformation error, process skill error, dan encoding error. Jawaban siswa yang mengalami kesalahan dianalisis dan diberi kode sesuai dengan deskriptor masing-masing prosedur Newman yang telah dijelaskan pada bab sebelumnya.

Hasil tes yang dianalisis merupakan jawaban siswa yang memberikan respon dalam menyelesaikan soal yang dilakukan pada saat tes. Siswa yang tidak memberi respon sama sekali tidak bisa diidentifikasi kesalahan yang dilakukannya. Seperti yang dinyatakan oleh Wijaya (2014) "missing response which were also categorized as no credit, were not coded and were excluded from the analysis because student's error cannot be identified from a blank response" yang artinya kurang lebih, jawaban siswa yang tidak ada atau tidak ada respon tidak dapat diidentifikasi atau dianalisis kesalahannya.

Dari hasil analisis jawaban siswa, siswa melakukan kesalahan pada semua soal. Dari 5 soal yang diberikan, kesalahan transformasi menjadi kesalahan terbanyak yang dilakukan siswa. Persentase kesalahan yang dilakukan siswa dapat dilihat pada Tabel 1, sedangkan untuk kesalahankesalahan siswa pada setiap soal dapat dilihat pada Tabel 2.

Dari hasil analisis jawaban siswa, peneliti memilih lima siswa yang mewakili semua kesalahan yang terjadi untuk diwawancarai. Berikut ini hasil analisis kesalahan yang didapat dalam penelitian ini.

Tabel 1. Persentase kesalahan yang dilakukan Siswa Berdasarkan Newman Error

\begin{tabular}{lcc}
\hline \multicolumn{1}{c}{ Kategori Newman Error } & Banyaknya Kesalahan & $\%$ \\
\hline Kesalahan Membaca (Reading) & - & - \\
Kesalahan Pemahaman (Comprehension) & 8 & 16 \\
Kesalahan Transformasi (Transformation) & 22 & 44 \\
Kesalahan pada Proses Perhitungan (Process Skill) & 20 & 40 \\
Kesalahan Kesimpulan (Encoding) & - & - \\
Total & 50 & 100 \\
\hline
\end{tabular}

Tabel 2 Kategori Kesalahan Siswa Berdasarkan Newman Error

\begin{tabular}{lccccccc}
\hline \multirow{2}{*}{ Kategori Kesalahan } & \multicolumn{5}{c}{ Nomor Soal } & \multirow{2}{*}{ Jumlah } \\
\cline { 2 - 6 } & 1 & 2 & 3 & 4 & 5 & - \\
Reading error & - & - & - & - & - & 8 \\
Comprehension error & - & - & - & 8 & - & 22 \\
Transformation error & 18 & - & 4 & - & - & 20 \\
Process Skill error & - & 8 & - & - & 12 & - \\
Encoding error & - & - & - & - & - & \\
\hline
\end{tabular}


Jurnal Riset Pendidikan Matematika, 5 (2), 2018 - 237

Yoga Baskara Setiawan, Hapizah Hapizah, Cecil Hiltrimartin

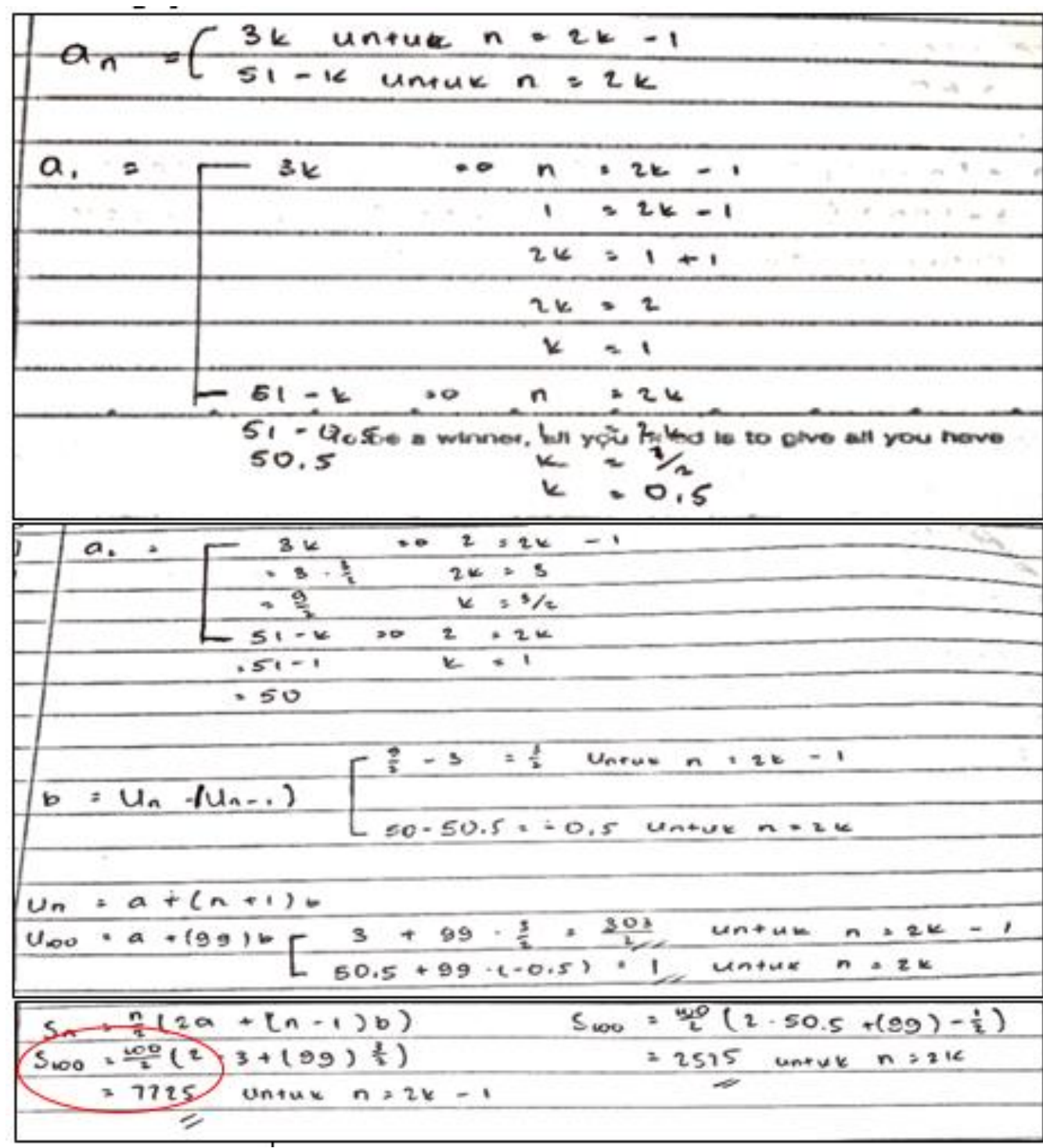

Gambar 1. Jawabsan Siswa 1 yang Salah dalam Memahami Soal Nomor 4

\section{Kesalahan Membaca}

Kesalahan membaca terjadi ketika siswa tidak mengenal simbol/lambang atau tidak memahami makna dari simbol/lambang/notasi pada soal. Dari lima soal yang diberikan, tidak terdapat siswa yang mengalami kesalahan membaca dalam mengerjakan soal.

\section{Kesalahan Pemahaman}

Kesalahan pada tahap pemahaman (comprehension error) terjadi ketika siswa tidak dapat memahami soal yang diberikan. Dari lima soal yang diberikan, siswa tidak memahami informasi yang diberikan terjadi pada soal nomor 4 . Berikut ini contoh jawaban siswa 1 yang mengalami kesalahan dalam memahami arti keseluruhan soal dapat dilihat pada Gambar 1.

Berdasarkan jawaban pada Gambar 1, jawaban siswa tidak dapat memahami secara keseluruhan arti soal atau dalam hal ini salah menafsirkan yang diinginkan soal. Hal ini terlihat dari jawaban siswa yang mencari jumlah dari masing-masing 100 suku pertama. Namun, pada soal no 4, yang diinginkan dari soal adalah mencari jumlah dari masing-masing 50 suku pertama. Hal ini didukung oleh hasil wawancara kepada Siswa 1. Pada wawancara, siswa 1 mengungkapkan bahwa siswa 1 tidak dapat memahami arti dari keseluruhan soal atau salah menafsirkan soal. Siswa tersebut menuturkan bahwa terlebih dahulu mencari beda tiap suku yang didapat dari suku kedua dikurang suku pertama. Kemudian dilanjutkan dengan mencari jumlah masingmasing 100 suku pertama dan tidak ditambah kedua hasil tersebut. Padahal yang seharusnya mencari jumlah masing-masing 50 suku pertama dan kemudian hasilnya dijumlahkan. 
Jurnal Riset Pendidikan Matematika, 5 (2), 2018 - 238

Yoga Baskara Setiawan, Hapizah Hapizah, Cecil Hiltrimartin

Tabel 3 Sub-Kategori pada Kesalahan Transformasi (Transformation Error)

\begin{tabular}{lllllll}
\hline \multicolumn{1}{c}{ Sub Kategori Kesalahan Transformasi } & \multicolumn{3}{c}{ Nomor Soal } & \multirow{2}{*}{ Jumlah } \\
\cline { 2 - 5 } & 1 & 2 & 3 & 4 & 5 & \\
\hline Menggunakan rumus/prosedur yang tidak relevan & 1 & - & - & - & - & 1 \\
Tidak mengetahui prosedur yang digunakan & 17 & - & 4 & - & - & 21 \\
\hline
\end{tabular}

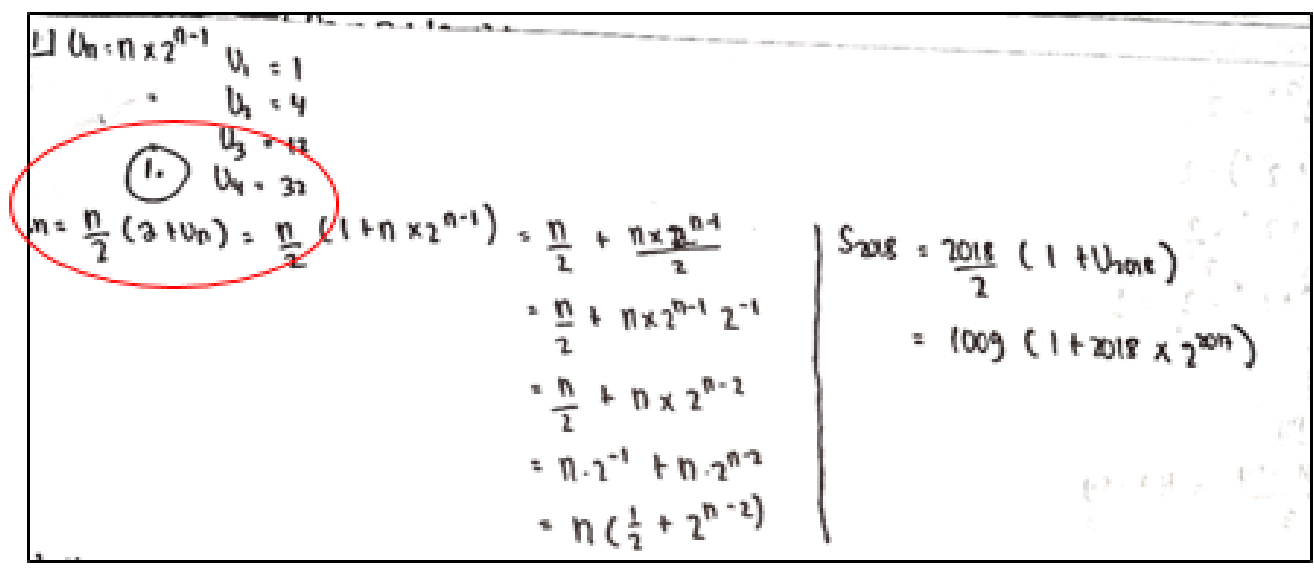

Gambar 2. Jawaban Siswa 2 yang Menggunakan Prosedur yang Tidak Relevan pada Soal Nomor 1

\section{Kesalahan Transformasi}

Kesalahan pada tahap transformasi (transformation error) merupakan kesalahan yang dilakukan siswa dimana siswa sudah bisa memahami soal tetapi keliru atau tidak tahu prosedur yang akan digunakan. Dari lima soal yang diberikan, terdapat dua macam kesalahan yang dilakukan oleh siswa, yaitu tidak menggunakan prosedur yang relevan dan tidak mengetahui prosedur yang akan digunakan. Sebaran keragaman yang dilakukan siswa pada tahap kesalahan transformasi dapat dilihat pada Tabel 3.

Siswa Menggunakan Prosedur/Rumus yang Tidak Relevan

Kesalahan siswa pada sub-kategori siswa menggunakan prosedur/rumus yang tidak relevan terjadi pada soal nomor satu. Berikut ini contoh jawaban siswa yang menggunakan rumus yang tidak relevan pada soal nomor satu dapat dilihat pada Gambar 2.

Gambar 2 merupakan contoh jawaban siswa dalam menyelesaikan soal nomor 1 . Siswa tersebut menggunakan prosedur yang tidak relevan. Hal ini terlihat dari jawaban siswa yang menyelesaikan soal dengan menggunakan prinsip-prinsip atau aturan-aturan dalam deret aritmatika. Padahal, pada soal nomor 1 yang seharusnya digunakan dalam menyelesaikan soal tersebut adalah dengan menggeneralisasi pola tersebut secara umum. Hal ini didukung oleh hasil wawancara kepada Siswa 2. Pada wawancara, siswa 2 mengungkapkan bahwa untuk mencari jawaban pada soal nomor 1 tersebut dilakukan dengan cara menggunakan rumus deret aritmatika karena siswa tersebut menganggap pola bilangan pada soal tersebut merupakan deret aritmatika. Padahal, prosedur tersebut tidak tepat karena pola tersebut bukan merupakan suatu deret aritmatika, tetapi pola bilangan tertentu. Sehingga untuk mencari jawaban dari soal nomor 1 menggunakan konsep pola bilangan secara umum.

Siswa tidak Tahu Prosedur/Rumus yang Akan Digunakan

Kesalahan pada sub-kategori ini terjadi pada soal nomor satu dan tiga. Adapun contoh jawaban siswa pada soal nomor 1 dan 3 seperti yang ditunjukan pada Gambar 3 dan Gambar 4.

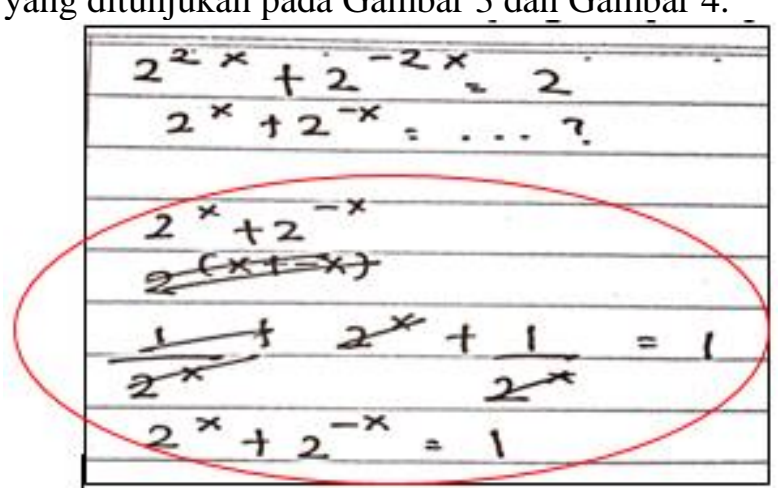

Gambar 3. Jawaban Siswa 3 yang Tidak Tahu Prosedur yang akan Digunakan pada Soal Nomor 3

Berdasarkan Gambar 3, siswa 3 tidak dapat menentukan prosedur penyelesaian yang diguna- 
kan untuk menyelesaikan permasalahan pada soal. Hal ini terlihat dari jawaban siswa yang hanya menuliskan diketahui dan ditanyakan pada soal. Pada langkah penyelesaian, siswa hanya menuliskan bentuk $2^{-x}+2^{x}$, pada baris selanjutnya siswa langsung menuliskan bentuk $2^{-x}+$ $2^{x}=1$ tanpa menuliskan langkah pengerjaan sebelumnya. Hal ini didukung oleh hasil wawancara kepada Siswa 3. Pada wawancara, siswa 3 mengungkapkan bahwa siswa tidak tahu sama sekali prosedur yang akan digunakan untuk menyelesaikan permasalahan pada nomor 3 . Hal ini terjadi dikarenakan siswa merasa tidak bisa menyelesaikan dan menganggap sulit permasalahan yang diberikan pada soal.

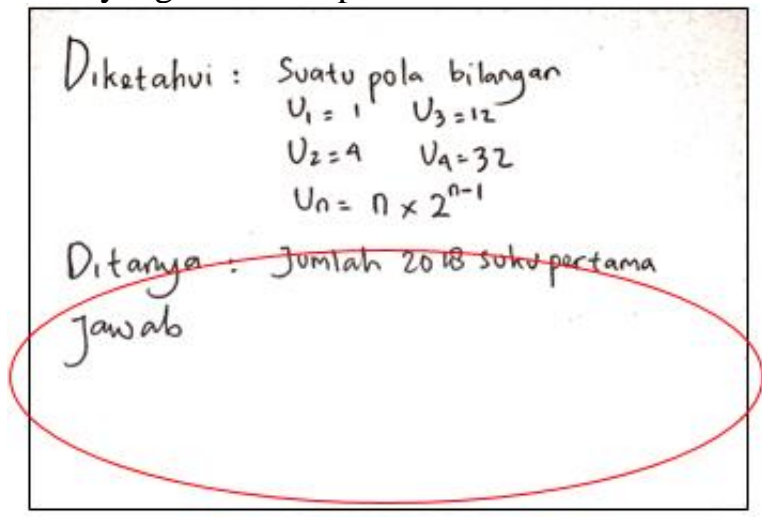

Gambar 4. Jawaban Siswa 4 yang Tidak Tahu Prosedur yang akan Digunakan pada Soal Nomor 1

Berdasarkan Gambar 4, siswa 4 tersebut tidak mengetahui prosedur atau rumus yang digunakan untuk menyelesaikan permasalahan pada soal. Hal ini terlihat dari jawaban siswa yang hanya menuliskan informasi yang diketahui dan yang ditanyakan pada soal, tetapi siswa tersebut sama sekali tidak menuliskan prosedur penyelesaiannya. Hal ini didukung oleh hasil wawancara kepada Siswa 4. Pada wawancara, siswa 4 mengungkapkan bahwa siswa 4 tersebut tidak tahu sama sekali prosedur yang akan digunakan untuk menyelesaikan permasalahan pada nomor 1. Hal ini terjadi dikarenakan siswa merasa tidak bisa menyelesaikan dan menganggap sulit permasalahan yang diberikan pada soal.

\section{Kesalahan Proses Perhitungan}

Kesalahan pada proses perhitungan terjadi ketika siswa telah bisa menentukan prosedur yang akan digunakan tetapi mengalami kesalahan pada proses perhitungan matematika. Dari 5 soal yang diberikan, terdapat dua kategori siswa yang mengalami kesalahan pada proses perhitungan, yaitu kesalahan dalam menggeneralisasi pola ke bentuk umum dan tidak melanjutkan prosedur atau langkah pengerjaan. Adapun sebaran dari dua kategori tersebut dapat dilihat pada Tabel 4.

\section{Kesalahan dalam Menggeneralisasi Pola Kebentuk Umum}

Kesalahan ini terjadi ketika siswa tersebut sudah mampu mengenali pola dengan tepat tetapi tidak dapat untuk menentukan pola secara umum. Kesalahan ini terjadi pada soal nomor 2. Adapun contoh jawaban siswa yang melakukan kesalahan ini ditunjukan pada Gambar 5.

Berdasarkan Gambar 5, jawaban siswa tersebut menunjukkan bahwa siswa belum mampu menjawab soal nomor 2 dengan tepat. Ini terlihat dari jawaban siswa yang belum menggeneralisasi pola fungsi tersebut ke bentuk umum. Siswa tersebut tidak menuliskan pola barisan fungsi sama sekali dan tidak menuliskan tanda dan seterusnya. Siswa tidak mampu menyelesaikan masalah pada soal dengan tepat meskipun siswa tersebut telah menggunakan prosedur yang tepat dalam menyelesaikan soal nomor dua. Hal ini diduga siswa mengalami tidak paham betul tentang konsep pola bilangan. Jadi, siswa tersebut dikategorikan melakukan kesalahan dalam menggeneralisasi suatu pola ke bentuk umum. Hal ini didukung oleh hasil wawancara kepada Siswa 4. Pada wawancara, siswa 4 mengungkapkan bahwa siswa tersebut sudah memahami apa informasi yang terdapat pada soal dan apa yang dicari dalam soal. Selain itu, siswa tersebut melakukan langkah pertama dengan tepat yaitu mencoba menemukan pola dari soal tersebut. Akan tetapi, siswa tersebut salah dalam menentukan pola umum dari soal tersebut. Ini terlihat dari jawabannya bahwa dia mengklaim $f_{2016}(2016)=f_{1}(2016)=2016$. Padahal, yang seharusnya $f_{2016}(2016)=$ $f_{3}(2016)=\frac{2015}{2016}$

\section{Tidak Melanjutkan Prosedur atau Langkah Pengerjaan}

Pada sub-kategori siswa melakukan kesalahan dalam operasi aljabar terjadi pada soal nomor 5. Adapun contoh jawaban siswa yang mengalami kesalahan ini ditunjukan pada Gambar 6. 
Jurnal Riset Pendidikan Matematika, 5 (2), 2018 - 240

Yoga Baskara Setiawan, Hapizah Hapizah, Cecil Hiltrimartin

Tabel 4 Sub-Kategori pada Proses Perhitungan (Skill Process Error)

\begin{tabular}{llllllc}
\hline \multicolumn{1}{c}{ Sub Kategori Kesalahan Proses Perhitungan } & \multicolumn{5}{c}{ Nomor Soal } & \multirow{2}{*}{ Jumlah } \\
\cline { 2 - 5 } & 1 & 2 & 3 & 4 & 5 \\
\hline Kesalahan menggeneralisasi pola ke bentuk umum & - & 8 & - & - & - & 8 \\
Tidak dapat melanjutkan prosedur atau langkah pengerjaan & - & - & - & - & 12 & 12 \\
\hline
\end{tabular}

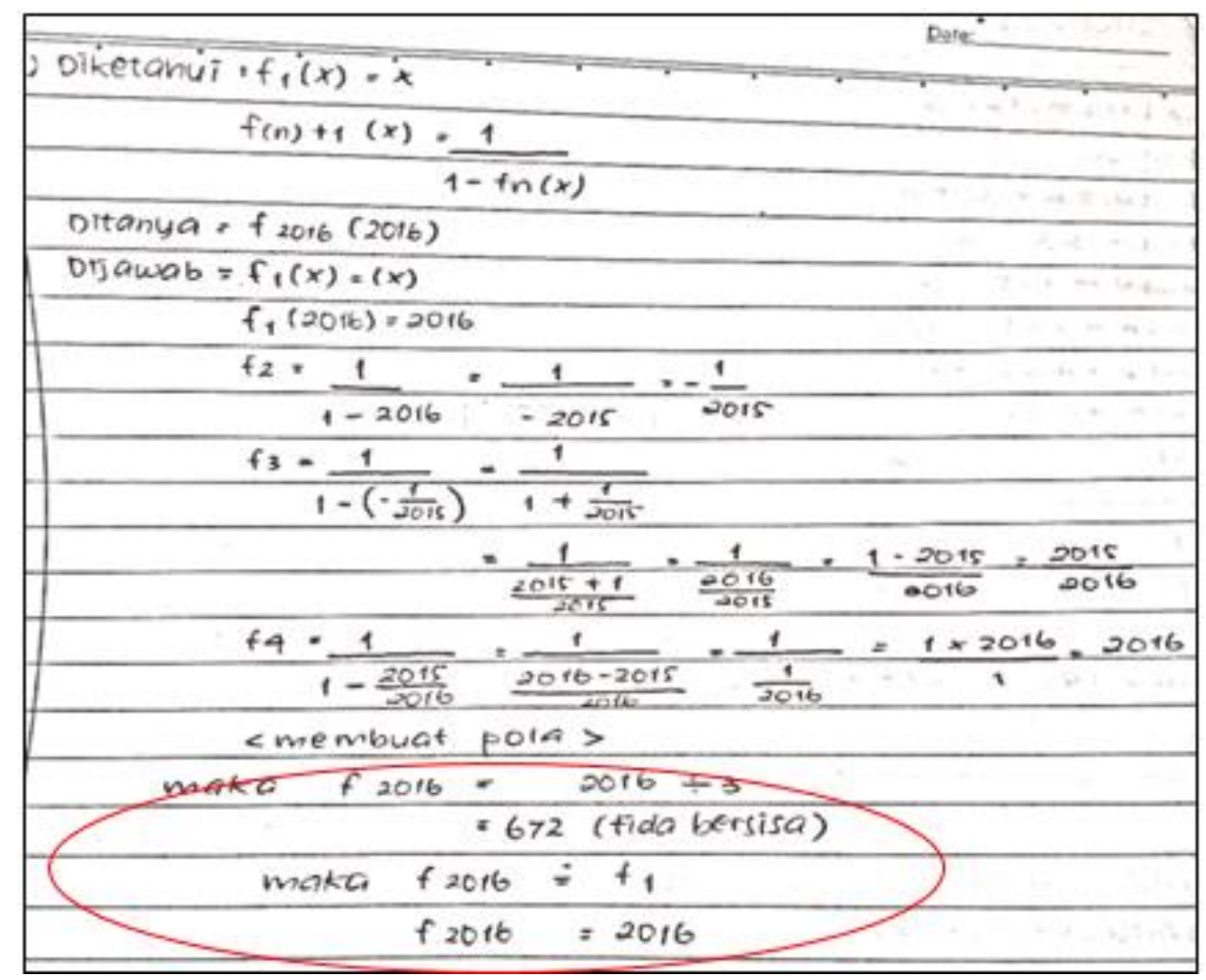

Gambar 5 Jawaban Siswa 4 yang Membuat Kesalahan Menggeneralisasi Pola ke Bentuk Umum pada Soal Nomor 2

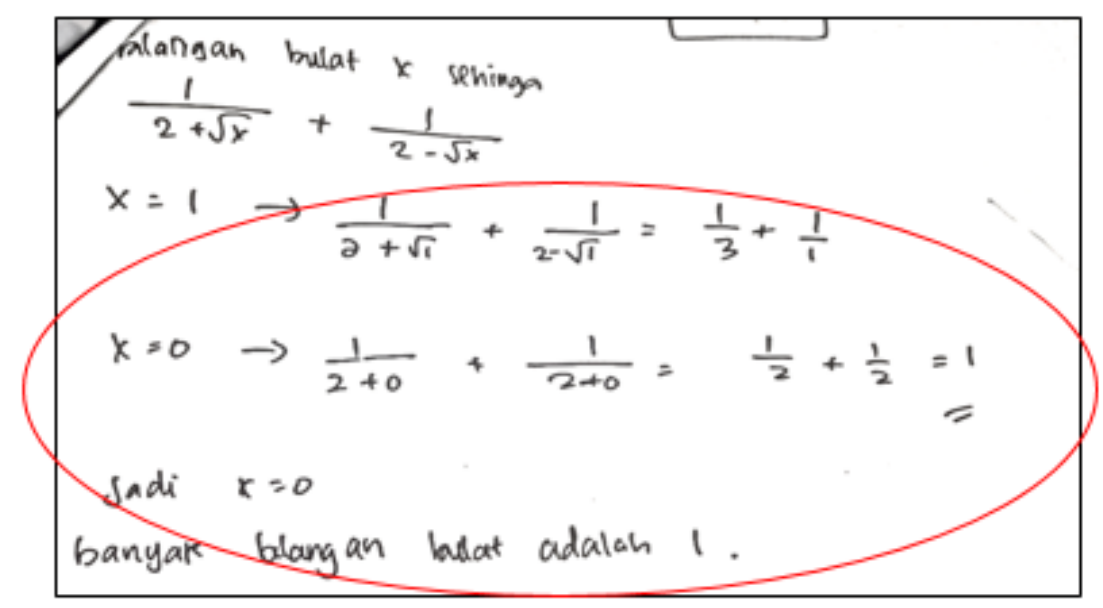

Gambar 6. Jawaban Siswa 5 yang Tidak Melanjutkan Prosedur atau Langkah Pengerjaan pada Soal Nomor 5

Berdasarkan Gambar 5, siswa belum menjawab soal nomor lima dengan tepat. Siswa tersebut telah melakukan prosedur dengan benar. Akan tetapi, siswa tersebut hanya mendapatkan satu solusi dan tidak menganalisis apakah masih ada solusi lainnya. Jadi, siswa tersebut dikategorikan melakukan kesalahan yaitu tidak melanjutkan prosedur pengerjaan. Hal ini didukung oleh hasil wawancara kepada Siswa 5. Pada wawancara, siswa 5 mengungkapkan bahwa siswa tersebut telah paham dengan informasiinformasi yang terdapat pada soal. Siswa tersebut juga telah melakukan prosedur yang tepat walaupun hanya cara coba-coba. Akan tetapi, 
siswa tersebut merasa sudah cukup dengan satu jawaban dan tidak menganalisis apakah masih ada penyelesaian lainnya. Siswa tersebut telah melakukan prosedur dengan benar. Akan tetapi, siswa tersebut hanya mendapatkan satu solusi dan tidak menganalisis apakah masih ada solusi lainnya. Padahal sebenarnya masih terdapat lima solusi lainnya yang mungkin. Jadi, siswa tersebut dikategorikan melakukan kesalahan yaitu tidak melanjutkan prosedur pengerjaan.

\section{Kesalahan Menyimpulkan}

Berdasarkan hasil analisis data jawaban siswa, dari 5 soal yang diberikan kepada 22 siswa, tidak ada siswa yang mengalami kesalahan pada penarikan kesimpulan. Siswa dikatakan mengalami kesalahan dalam penarikan kesimpulan apabila siswa tersebut telah melewati empat tahap sebelumya (reading, comprehension, transformation, dan process skill) dengan benar, tetapi tidak bisa menuliskan solusi yang tepat (Suyitno \& Suyitno, 2015).

\section{Pembahasan}

Berdasarkan hasil analisis data lembar jawaban siswa dan wawancara, dari lima jenis kesalahan berdasarkan prosedur Newman error, siswa mengalami kesalahan pada tiga tahapan. Kesalahan yang terjadi yaitu pada tahap pemahaman soal (comprehension error), tahap transformasi (transformation error), dan proses perhitungan (process skill error). Sementara pada tahap penarikan kesimpulan (encoding error) dan tahap membaca (reading error), tidak ditemukan kesalahan.

Kesalahan pada tahap pemahaman (comprehension error) terjadi ketika siswa tidak dapat memahami soal yang diberikan. Kesalahan pada tahap pemahaman soal (comprehension) hanya terjadi pada soal nomor empat. Berdasarkan hasil tes, menunjukan bahwa siswa tidak memahami informasi yang diberikan pada soal. Selaras dengan hasil wawancara mengungkapkan bahwa hanya sebagian informasi yang diberikan pada soal yang dapat diterima oleh siswa. Hal tersebut terjadi karena siswa tidak memaknai dalam membaca kalimat pada soal dan terlalu cepat mengambil kesimpulan informasi yang terdapat dalam soal. Sehingga ada beberapa informasi dari soal yang salah ditafsirkan oleh siswa. Kesalahan dalam memahami informasi pada soal terjadi pada soal dengan lingkup materi pola bilangan, barisan dan deret. Jika diperhatikan, tidak ditemukan kesalahan pada empat soal lainnya, dikarenakan keempat soal lainnya jelas apa yang diketahui dan ditanya. Hal ini sesuai dengan penelitian Wijaya (2014) menyatakan bahwa kesalahan dalam memahami soal merupakan salah satu kesalahan yang banyak terjadi pada siswa.

Kesalahan pada tahap transformasi (transformation error) terjadi ketika siswa telah mampu memahami informasi dan apa yang ditanya pada soal tetapi mengalami kesalahan dalam menentukan atau keliru menggunakan prosedur yang digunakan. Dalam penelitian ini terdapat dua macam kesalahan yang dilakukan siswa pada tahap transformasi, yaitu menggunakan rumus atau prosedur yang tidak relevan dan tidak tahu prosedur atau rumus yang digunakan. Diantara kedua kesalahan tersebut, kesalahan terbanyak yang dilakukan siswa adalah tidak tahu prosedur/rumus yang akan digunakan. Kesalahan ini terjadi pada soal nomor 1 dan nomor 3. Pada soal nomor 1, siswa melakukan kesalahan tersebut karena kurangnya pemahaman konsep siswa pada materi pola bilangan. Pada soal nomor 3, siswa melakukan kesalahan tersebut dikarenakan belum mempunyai pemahaman yang baik tentang faktorisasi aljabar dan eksponen. Selain itu, terdapat kesalahan lainnya yaitu kesalahan dalam menggunakan prosedur atau rumus untuk menyelesaikan soal. Kesalahan ini terjadi pada soal nomor 1. Hal ini terjadi karena siswa tersebut belum bisa membedakan mana yang merupakan deret aritmatika dan deret secara umum dan siswa tersebut belum mempunyai pemahaman yang baik tentang konsep pola bilangan. Hal ini sesuai dengan penelitian Ridwan (2016) yang menyatakan bahwa kesalahan siswa dalam menyelesaikan soal aljabar diantaranya kesalahan menentukan rumus atau prosedur dan tidak tahu rumus yang digunakan

Kesalahan pada proses perhitungan terjadi ketika siswa telah bisa menentukan prosedur yang akan digunakan tetapi mengalami kesalahan pada proses matematika. Dalam penelitian ini, terdapat dua macam siswa yang mengalami kesalahan pada proses perhitungan, yaitu kesalahan dalam menggeneralisasi pola ke bentuk umum dan tidak melanjutkan prosedur atau langkah pengerjaan. Hal ini sesuai dengan Ridwan (2016) yang mengatakan bahwa salah satu kesalahan siswa dalam menyelesaikan soal aljabar adalah tidak melanjutkan prosedur penyelesaian. Dari kedua kesalahan tersebut, kesalahan terbanyak yang dilakukan siswa yaitu tidak melanjutkan prosedur atau langkah penyelesaian. Siswa telah mampu menemukan prosedur yang tepat untuk menyelesaikan soal tersebut. Siswa tersebut juga 
telah mendapatkan satu solusi yang diingikan. Akan tetapi, siswa tersebut tidak menganalisis apakah ada solusi-solusi lainnya dan hanya yakin dengan jawaban yang didapatnya saja. Kesalahan ini terjadi karena siswa tersebut kurang memahami materi operasi aljabar. Hal ini sesuai dengan penelitian Ridwan (2016) yang menyatakan bahwa salah satu alasan siswa melakukan kesalahan dalam menyelesaikan soal aljabar adalah kurangnya pengetahuan tentang operasi aljabar.

Sedangkan untuk kesalahan dalam membaca (reading) dan penarikan kesimpulan (encoding), dalam penelitian ini tidak ditemukan siswa yang mangalami kesalahan pada tahap tersebut. Dari lima soal yang diberikan, siswa mengalami kesalahan pada tiga tahap, yaitu kesalahan dalam pemahaman (comprehension error), kesalahan transformasi (transformation error), dan kesalahan dalam proses perhitungan (process skill error). Dari tiga kesalahan yang terjadi, kesalahan transformasi menjadi yang paling dominan terjadi. Hal ini selaras dengan penelitian Wijaya (2014) dan Hadi, Retnawati, Munadi, Apino, dan Wulandari (2018) yang menyatakan bahwa dari kelima jenis kesalahan, kesalahan dalam pemahaman dan transformasi merupakan kesalahan yang paling sering dilakukan siswa.

\section{SIMPULAN}

Berdasarkan hasil penelitian dan pembahasan dapat disimpulkan bahwa kesalahan siswa SMP Negeri 1 Palembang dalam menyelesaikan soal Olimpiade SMP konten aljabar yaitu pada tahap memahami soal (comprehension error), siswa melakukan kesalahan dalam memahami makna keseluruhan soal. Pada tahap transformasi (transformation error), siswa menggunakan prosedur yang tidak relevan, dan siswa tidak bisa menentukan prosedur yang harus digunakan. Sedangkan pada tahap proses matematika (process skill error), siswa melakukan kesalahan dalam menggeneralisasi pola ke bentuk umum, dan tidak melanjutkan prosedur atau langkah penyelesaian.

Berdasarkan temuan temuan tersebut, beberapa saran untuk dapat ditindaklanjuti. Pertama, bagi guru, untuk mengatasi kesalahan dalam menyelesaikan soal Olimpiade SMP konten aljabar disarankan agar membiasakan siswa berlatih dengan soal-soal setingkat olimpiade saat pembelajaran di kelas atau memberikan pembinaan yang tepat kepada siswa agar terbiasa dengan soal-soal setingkat olimpiade. Kedua, bagi peneliti lain dapat membantu memberikan solusi untuk mengatasi kesalahan ini dengan mengembangkan model pembinaan olimpiade matematika SMP konten aljabar.

\section{DAFTAR PUSTAKA}

Abdullah, A. H., Abidin, N. L. Z., \& Ali, M. (2015). Analysis of students' error in solving higher order thinking skills (HOTS) problem for the topic of fraction. Asean Social Science, 11(21), 113-142. doi:http://dx.doi.org/10.5539/ass.v11n21p 133

Direktorat Dikdasmen Kemendikbud RI. (2017). Panduan olimpiade sains nasional (OSN) dan lomba sains tingkat internasional sekolah menengah pertama tahun 2017. Jakarta: Author.

Direktorat PSMP Kemendikbud. (2016). Pengumuman hasil OSN matematika dan ilmu pengetahuan alam SMP tingkat nasioanl tahun 2016. Jakarta: Author.

Direktorat PSMP Kemendikbud. (2017). Pengumuman hasil OSN matematika dan ilmu pengetahuan alam SMP tingkat nasioanl tahun 2017. Jakarta: Author.

Hadi, S., Retnawati, H., Munadi, S., Apino, E., \& Wulandari, N. F. (2018). The difficulties of high school students in solving higherorder thinking skills problems. Problems of Education in the $21^{\text {st }}$ Century, 76(4), 520-532.

Herutomo, R. A., \& Saputro, T. E. M. (2014). Analisis kesalahan dan miskonsepsi siswa kelas VIII pada materi aljabar. Edusentris, Jurnal Ilmu Pendidikan dan Pengajaran, 1(2), 134-145. Retrieved from http://ejournal.sps.upi.edu/index.php/edus entris/article/view/140/110

Lipianto, D., \& Budiarto, M. T. (2013). Analisis kesalahan siswa dalam menyelesakan soal yang berhubungan dengan persegi dan persegi panjang berdasarkan Taksonomi Solo Plus pada kelas VII. MATHEdunesa, 2(1), 1-8.

NCTM, (2008). Principles and standards for school mathematics. Reston, VA: Author.

Ridwan, T. (2016). Analisis kesalahan siswa dalam menyelesaikan masalah aljabar. Skripsi sarjana tidak diterbitkan. Universitas Nusantara PGRI, Kediri.

Singh, P., Rahman, A. A., \& Hoon, T. S. (2010). The Newman procedure for analyzing primary four pupils errors on written mathematical task: a malaysian 


\section{Jurnal Riset Pendidikan Matematika, 5 (2), 2018 - 243}

Yoga Baskara Setiawan, Hapizah Hapizah, Cecil Hiltrimartin

perspective. Procedia Social and Behavioral Sciences, 8, 264-271.

Suhaedi, D. (2013). Peningkatan kemampuan komunikasi matematis, berpikir aljabar, dan disposisi matematis siswa SMP melalui pendekatan pendidikan matematika realistik Indonesia. Disertasi doctoral tidak dipublikasikan. Universitas Pendidikan Indonesia, Bandung.

Sukmawati, A. (2015). Berpikir aljabar dalam menyelesaikan masalah matematika. Math Didactic: Jurnal Pendidikan Matematika, 1(2), 89-95.

Suyitno, A., \& Suyitno, H. (2015). Learning therapy for students in mathematicts communication correcrtly based on aplication of Newman procedure (A case of Indonesian student). International Journal of Education and Research, 3(1), 529-537
Tadda, M. (2016). Analisis kesalahan siswa dalam menyelesaikan soal-soal aljabar berdasarkan gender. Prosiding Seminar Nasional Universitas Cokroaminoto Palopo, 2(1), 347-354.

Ukhti, L. (2013). Analisis kemampuan siswa dalam menyelesaikan soal olimpiade matematika tingkat kabupaten/kota pada siswa kelas XI SMA Teuku Nyak Arif Fatih Bilingual School Kota Banda Aceh Tahun 2013. Prosiding Seminar Nasional Matematika dan Terapan 2013 (SiManTap 4), 279-288.

Wijaya, A. (2014). Identifying (Indonesian) students' diffuculties in solving contextbased (PISA) mathematics tasks. Proceeding of International Seminar on Innovation in Mathematics and Mathematics Education. 